\title{
Studies of Water Needs of Potatoes According to Climatic Conditions Cultivated in Bioinoculated Sandy Soil
}

\author{
Shereen A. H. Saad ${ }^{1}$ and Salem E. A. ${ }^{2}$ \\ ${ }^{I}$ Physics and Chemistry Dept., Soils, Water and Environment Research Institute, Agricultural Research \\ Center, Giza, Egypt. \\ ${ }^{2}$ Biolological Agriculture Dept., Central Laboratory for Agricultural Climate, Agricultural Research \\ Center, Dokki, Giza, Egypt. \\ Received: 15 Oct. 2020 / Accepted 30 Nov. 2020 / Publication date: 05 Dec. 2020
}

\begin{abstract}
Agriculture sustainably and shortages in the water supply are the most critical issues facing the world in the course of climate change conditions. Deficit irrigation improves water use efficiency, but the reduced water input often limits plant growth and nutrient uptake. Advances in biological sciences hold tremendous promise for surmounting many of the major challenges confronting the world. Microbial inoculants may improve crop productivity even in low-input agriculture by different ways. It helps the land plants to acclimatize the biotic and abiotic conditions for their better survival, growth and development beside it can support the sustainable agriculture systems. To evaluate this, a field experiment in thirty-six containers with dimensions of ( $0.80 \mathrm{~m}$ length, $0.30 \mathrm{~m}$ width and $0.40 \mathrm{~m}$ depth) that filled with sandy soil was carried out for 2 years. In both years, the experiment was set up in a split plot design where, irrigation levels $(60,80$ and $100 \%)$ from soil water depletion calculated according to climatic condition as the main plot and four treatments of bioinoculation (Biogen, Mycorrhizae, Mix of them and without adding as control) were applied as sub main with three replicates. The results showed that bioinoculation with tested bioferilizers helped potato plants withstand deficit irrigation although, proper irrigation level is a deciding parameter for the optimum potato yield quantity and quality. The significant effect of studied bioinoculation pronounced by improving the tested vegetative growth and yield characteristics as well as availability of soil nutrients N, P, K and soil aggregates beside soil microorganisms, this beneficial emerging properties could be efficiently exploited in the sustainable agriculture. Results appeared that the combined effect of $80 \%$ irrigation level and inoculation with Mycorrhizae registered the highest values of studied characteristics than other treatments which reflected on quantity and quality of potato yield.
\end{abstract}

Keywords: Crop water requirements, Table potatoes and Bioinoculation

\section{Introduction}

Microbial inoculants are of growing interest for their potential role in every ecosystem; beneficial soil microorganisms play key roles in the maintenance of long-term soil fertility and health by the reduction of chemical inputs in agriculture, promotion of plant nutrition and production safe and highquality food (Giovannini et al., 2020).

Recently, arbuscular mycorrhizal fungi (AMF) represent a key factor for optimization of crop productivity, especially in the low-input agriculture (Deja-Sikora et al., 2020). According to Janet Didur, (2020) mycorrhizae from the Greek meaning 'mykos' as fungus and 'riz' as roots refers to a symbiotic association between a fungus and roots of a vascular plant that provides the fungus with relatively constant and direct access to carbohydrates, in return the plant gains the benefits of the mycelium's higher absorptive capacity for water and mineral nutrients due to the comparatively large surface area of mycelium to root ratio. This improves the plant's water and mineral absorption capabilities by both physical and chemical mechanisms. Mycorrhizal mycelia are much smaller in diameter than the smallest root, and thus can explore a greater volume of soil, providing a larger surface area for absorption, this beneficial alliance accelerates root development and stimulates plant growth especially in nutrient-poor soils. It can increase effectiveness of absorbing capability of surface host root as much as ten times especially, ions such as $\mathrm{P}, \mathrm{Zn}$ and $\mathrm{Cu}$ do not diffuse readily through soil

Corresponding Author: Shereen A. H. Saad, Physics and Chemistry Dept., Soils, Water and Environment Research Institute, Agricultural Research Center, Giza, Egypt.

E.mail:- kh_r_2000@hotmail.com 
beside increasing root uptake of $\mathrm{N}, \mathrm{P}, \mathrm{K}, \mathrm{Zn}, \mathrm{Cu}, \mathrm{S}, \mathrm{Fe}, \mathrm{Ca}, \mathrm{Mg}$ and $\mathrm{Mn}$ furthermore, mycorrhizal plants are often more resistant to diseases (Smith and Smith, 2011). AMF also can facilitate the completion of biogeochemical cycles, increase carbon sequestration and soil aggregation and the content of healthpromoting phytochemicals thereby mycorrhizae can be important for soil health and contribute to creating a better more conductive environment around the root zone for the good biology to grow and that in turn helps generate better soil health (Giovannini et al., 2020). Thereby, Mycorrhizal plants often display enhanced tolerance to abiotic stress factors (e.g., drought or salinity), these plant-associated microorganisms can alleviate the negative impacts by modulating the level of plant stress response (Deja-Sikora et al., 2020).

Many plant species show large positive growth response to AMF colonization, which usually grow healthier, stronger tend to develop faster than those without inoculation to be more resistant even in the low-input agriculture. Volpato et al. (2020) emphasized that mycorrhizal fungi colonize the roots of more than $90 \%$ of plant species having mutual plant and fungus benefit and this symbiosis can improve the nutritional status and growth of plants under both optimal and restricted water levels while, AM fungi represent an important biological factor for plants to thrive in water-limited conditions not only by increasing the supply of nutrients, but also by helping plants to resist water stress by improving stomatal conductance, photosynthetic phosphorus use, proline accumulation and display greater hydraulic conductivity in roots and reduced transpiration rate under drought stress. Yooyongwecha et al. (2016) concluded that inoculation of AMF in sweet potato plants improved plant growth characteristics and enhanced water deficit tolerance via soluble sugars and free proline accumulation. Deja-Sikora et al. (2020) mentioned that AMF hyphae act as root system extension due to high absorptive capacity of extraradical mycelium that gains an easier acquisition of soil water and slowly diffusing mineral compounds in particular phosphorus and nitrogen ions, which resulted improveing plant nutritional status and fitness. Thus, that can be encourage the wide application of AMF-based natural biofertilizers to support the sustainable agriculture systems (Lone et al., 2015).

Among microbial inoculants is Biogen, El-Salhy et al. (2010) pointed to a possibility of reducing the amount of chemical fertilizers added to Citrus reticulate trees inlaid with bitter orange by adding a biogen-enriched container containing Azotobacter sp. which caused a significant increase in the characteristics of vegetative growth, leaf area and carbohydrate ratio to nitrogen in branches compared to chemical fertilizers. These results may be due to the biological fertilization factors in biogen which containing bacteria (Azotopacter chroococcum + Azosperillium brasilense) and potassium-containing containers (Bacillus circulans) significantly outweighed the rest of the fertilizer treatments (Alalaf and Hadeed, 2020). Sharma et al. (2019) exhibited that bacterium Azotobacter chroococcum able to install $10 \mathrm{mg}$ nitrogen per gram of carbohydrates in addition to fixing nitrogen, it can produce some amino acids and vitamins such as thiamine B1 and riboflavin B2 and some growth regulators like indole IAA and gibberelin $\mathrm{GA}_{3}$.

Several studies aimed to detecting the best performing bacterial strains, to be used in combination with selected AMF as biofertilizers and biostimulants in innovative and sustainable food production systems, it showed that the multiple services provided by AMF depend on the synergistic activity of diverse bacterial communities living in the mycorrhizosphere, strictly associated with their spores and extraradical mycelium and playing diverse plant growth-promoting roles, from nitrogen fixation and $\mathrm{P}$ solubilization and mineralization to the production of indole acetic acid (IAA), siderophores, and antibiotics (Giovannini et al., 2020). It can be coinciding by Xavier and Germida, (2002) who notice that AMF is works synergistically with symbiotic and asymbiotic $\mathrm{N}$ fixing bacteria while with symbiotic $\mathrm{N}$ fixers there is improved nodulation and AMF root colonization, with significant benefit to plant growth. This observation was in line with the other study that demonstrated the enhancement of potato (cv. Yungay) growth parameters upon mycorrhization with R. intraradices due to greater uptake of $\mathrm{P}$, $\mathrm{Fe}$, and $\mathrm{Mg}$ as well as higher efficiency of P utilization (Deja-Sikora et al., 2020). El-Sayed et al. (2015) used mix of different types of bacteria and VAM as biofertilizers and compost to enhance yield and quality of potato cultivated in sandy soil. They found that compost at $23.8 \mathrm{tha}-1+$ bio-fertilizer resulted in a significant increase in marketable yield.

Potato (Solanum tuberosum L.) belongs to the most meaningful horticultural species grown worldwide for food and industrial purposes. Potato plants are known to be sensitive to water stress and have a low P uptake, due to their rarefied root hair system. An economic potato yield can only be achieved through a suitable irrigation and through fertilization (Volpato et al., 2020). The inoculants 
can actually help the potato root system overcome different challenges associated with different soils. AMF symbiosis have remarkable role in sustainable growth and development of Potato plants to acclimatize the biotic and abiotic conditions for their better survival, growth and development (Lone et al., 2015). Based on the results obtained by Susiana et al. (2019) the application of mycorrhizae proves to be able to increase potato plant growth and seed productivity. Also, Volpato et al. (2020) mentioned that, AM fungi can alleviate abiotic stress caused by low levels of $\mathrm{P}$ and/or a partially localized water deficit. Mycorrhizae is also proven to delay the occurrence of infection in potato (Deja-Sikora et al., 2020).

In this investigation, we aimed to determine if water needs of potatoe were affected by commercial bioinoculations (Mycorrhizae or Biogen or the Mix of them) under three irrigation levels treatments $(60,80$ and $100 \%)$ of water depletion and studying impacts of these treatments on potatoes yield quantity and quality through the analysis of some indicating factors. Also study the influence of these treatments on some ecosystem factors related to soil health like availability of soil nutrients $\mathrm{N}, \mathrm{P}$, $\mathrm{K}$ and soil aggregates and soil microorganisms, in attempt to implement intensive sustainable practice for potato crop cultivation.

\section{Material and Methods}

An open field experiment was carried out through installing a drip-irrigation system above thirtysix containers that combined different water requirements of soil water depletion levels from available water as a percentage from the fled capacity and testing the Bioinoculation delivered within the active root zone.

\section{Location site, crop details and soil description}

This study was performed on open field of Dokki side, belongs to the Central Laboratory for Agricultural Climate (CLAC), Agricultural Research Center (ARC), at El-Giza Governorate, Egypt which situated at $30^{\circ} 03^{\circ} \mathrm{N}$ latitude, $31^{\circ} 20^{\prime} \mathrm{E}$ longitude and mean altitude $70 \mathrm{~m}$ above sea level. The experimental area has an arid climate condition with cool winters and hot dry summers and the monthly mean climatic data for both growing season of 2019 and 2020 were summarizes in Table (1).

Table 1: Monthly growing season climatic data for the experimental site.

\begin{tabular}{|c|c|c|c|c|c|c|c|c|c|}
\hline \multirow{2}{*}{\multicolumn{2}{|c|}{ Parameters }} & \multicolumn{4}{|c|}{ Season of 2019} & \multicolumn{4}{|c|}{ Season of 2020} \\
\hline & & Feb. & Mar. & Apr. & May & Feb. & Mar. & Apr. & May \\
\hline \multirow{2}{*}{ Temp. $C^{\circ}$} & Max & 17.6 & 20.3 & 22.0 & 17.6 & 17.3 & 20.3 & 22.6 & 25.1 \\
\hline & Min & 7.2 & 8.6 & 11.6 & 7.2 & 7.6 & 9.9 & 11.2 & 15.5 \\
\hline \multicolumn{2}{|c|}{ RH_AVG\% } & 76.8 & 72.6 & 72.0 & 71.7 & 76.8 & 50.8 & 47.7 & 50.7 \\
\hline \multicolumn{2}{|c|}{ Wind speed $(\mathrm{m} / \mathrm{sec})$} & 1.8 & 1.8 & 1.7 & 1.7 & 1.8 & 2.3 & 2.3 & 2.4 \\
\hline \multicolumn{2}{|c|}{ Radiation $\mathrm{MJ} / \mathrm{m}^{2}$} & 94.4 & 126.3 & 144.7 & 145.1 & 94.4 & 105.3 & 139.8 & 144.3 \\
\hline \multicolumn{2}{|c|}{ Et $_{\text {o }}$ mday $^{-1}$} & 2.3 & 3.3 & 4.3 & 5.1 & 2.3 & 3.5 & 5.0 & 5.8 \\
\hline
\end{tabular}

Daily soil water depletion and crop water requirements were estimated with a computer software IRRICLAC program that consider the weather conditions and soil water characteristics. Daily weather data was used to calculate reference evapotranspiration (ET $)$ according to Penman-Monteith equation. The applied irrigation water were adjusted by using thirty-six containers of the size $0.80 \mathrm{~m} \times 0.30 \mathrm{~m}$ in area and $0.40 \mathrm{~m}$ depth which stacked adjacent with an inter-treatments distance. Water flow meters were fixed in each treatment to control the delivery of the amounts of water irrigation $\left(\mathrm{L} / \mathrm{m}^{2}\right)$. All the experimental plots received the same amount of water by a gate valve of $16 \mathrm{~mm}$ that was fixed in each headline of the laterals. The soil at the experimental site is classified as a sandy soil and the physical and chemical analyses of the soil, before adding the mixed fertilizer were presented in Table (2) that estimated according to A.O.A.C., 2005.

Table 2: Physical and chemical properties of the soil of the experimental area.

\begin{tabular}{ccccccccc}
\hline Soil depth & Texture & $\begin{array}{c}\text { Sand } \\
(\mathbf{\%})\end{array}$ & $\begin{array}{c}\text { Silt } \\
(\mathbf{\%})\end{array}$ & $\begin{array}{c}\text { Clay } \\
(\mathbf{\%})\end{array}$ & $\begin{array}{c}\text { Bulk density } \\
\left(\mathbf{g m ~ c m}^{-3}\right)\end{array}$ & $\begin{array}{c}\text { EC 1:5 } \\
\left(\mathbf{d S ~ m}^{-1}\right)\end{array}$ & $\begin{array}{c}\text { pH } \\
(\mathbf{1 : 2 . 5})\end{array}$ & $\begin{array}{c}\text { Total } \\
\mathbf{C a C O}_{\mathbf{3}}(\mathbf{\%})\end{array}$ \\
\hline $\mathbf{0 0 - 2 0}$ & Sandy & 97.2 & 2.0 & 0.8 & 1.4 & 3.81 & 7.8 & 2.6 \\
\hline
\end{tabular}


Potato (Solanum tuberosum, L.) Spunta cultivar was cultivated in $12^{\text {th }}$ Feb. 2019 and 2020 in both growing seasons with $30 \mathrm{~cm}$ planting distances, so, there were 3 plants in each container to record its properties of vegetative growth and parameters of yield quantity and quality. The experimental plants were fertilized before sowing according to the standard recommendation of the Ministry of Agriculture (Potato cultivation and production, 2005), and irrigated by drip irrigation system to meet the crop consumptive use for each water depletion treatment (liter/period) by using graduated cylinder. In the same time all the other agriculture practices were performed according to the standard recommendations for commercial growers, by (Vegetable cultivation guide, 2014).

\section{Experimental design and treatments:-}

Three treatments of irrigation levels (60, 80 and 100\%) depending on the actual plant water use and the soil water depletion from the field capacity, with three additions of commercial bioinoculations (Biogen, Mycorrhizaen, Mix of them and without adding as control) were tested in thirty-six containers with dimensions of $(0.80 \mathrm{~m}$ length, $0.30 \mathrm{~m}$ width and $0.40 \mathrm{~m}$ depth) that filled with sandy soil. The applied water was adjusted by using separate unit of containers to beginning irrigation till the water leaching appear from container below, and then the irrigation stops and estimated the amount of leached water, and the water amount by subtracted from the amount of water added. The actual amount of water retained in the soil was confirmed and available for plant use, and on the basis of which other irrigation levels were modified and determined. The experiment was set up in a split plot design where, irrigation levels $(60,80$ and $100 \%)$ from soil water depletion were applied as the main plot and four treatments of bioinoculation were applied as sub main with three replicates.

\section{Characterization of microbial Biofertilizers:}

The mycorrhizal fungal inoculum "Mycorrhizen" was bought from Microbiology department, Institute of Lands, Water and Environment, Agricultural Research Center. The inoculum was spores of different species pieces of infected roots mixed with soil. The contents of the inoculum bag was mixed with a sugar solution (100 g sugar / $100 \mathrm{ml}$ water) and were mixed with soil in the planting hole in amount of $25 \mathrm{~g}$ just before potato seeds sowing (Biermann and Linderman, 1983).

The bacterial inoculum "Biogen" was bought from The Public Authority for the Agricultural Budget Fund, Agricultural Research Center. Contents of the inoculum bag were mixed with gum (supplied with the bag), and were placed in the planting hole in amount of $25 \mathrm{~g}$ just before potato seeds sowing. For mixed treatment, equal amounts of Mycorrhizen and Biogen were mixed thoroughly and $25 \mathrm{~g}$ of the mix was placed in the planting hole just before potato seeds sowing.

\section{Crop parameters:-}

A sample of three plants was taken from each treatment replicate to measure the vegetative physical properties of:-

- Plant height was estimated from the first internode to the apex in $(\mathrm{cm})$ by a meter.

- Number of leaves per plant was counted.

- Plant fresh weight was determined in ( $\mathrm{g}$ ) by a balance.

- Leaf area was recorded $\left(\mathrm{cm}^{2}\right)$ by using a digital leaf area meter (LI-300 portable area meter produced by LI- COR, Lincoln, Nebraska, USA).

The Vegetative chemical properties were:-

- Total chlorophyll content of the six mature leaf was measured using chlorophyll meter (Spad-501) produced by Minolta Co., Japan.

- Plant dry weight (g), was determined by drying a mixed small pieces of the fresh parts at $70^{\circ} \mathrm{C}$ until constant weight was reached.

The Yield quantity and quality of:-

- Total tuber yield in number per plant

- Total tuber yield in weight per plant $(\mathrm{kg})$ :-

Tubers of every plant were sorted according to the Ministerial Decree No. 651/1978 issued by the Egyptian Organization for Standardization and Quality Control (EOS), marketable and unmarketable yield in weight per plant $(\mathrm{kg})$ : tubers were weighed and recorded as $\mathrm{Kg} / \mathrm{plant}$. 
- Firmness was measured using Magness and Ballouf pressure tester equipped with 3/16 inch ${ }^{2}$ plunger as $\mathrm{g} / \mathrm{cm}^{2}$ after Wills et al. (1982).

- Tuber volume of ten tubers was determined in $\mathrm{cm}^{3}$ by measuring the water volume displaced by immersing the tuber in a graduated jar filled with water.

- Total carbohydrates were determined as $\mathrm{g} / 100 \mathrm{~g}$ dry weight according to Smith et al. (1956).

- Starch was determined as $\mathrm{g} / 100 \mathrm{~g}$ dry weight by substracting the total soluble sugars from the total carbohydrates according to AOAC (1975).

Weight of starch= weight of obtained glucose $\mathrm{x} 0.95$.

\section{Soil nutrition availability:-}

The macronutrient, available nitrogen, phosphorus and potassium content within $20 \mathrm{~cm}$ soil profile was determined using Kjeldahl method described by FAO (1980) for nitrogen, using spectrophotometer according to Watanabe and Olsen (1965) for Phosphorus and using Flame photometer as described by Chapman and Pratt (1961) for Potassium.

\section{Examination of AM fungi infection by root staining}

One month after sawing, roots staining technique was applied in some random samples according to Koske and Gemma (1989) to check success of root penetration by VAM. Root samples were dipped in water to remove adhering soil, rinsed and cut into 0.5 to $1 \mathrm{~cm}$ segments cleared by immersing in $\mathrm{KOH}(10 \%)$ for $45 \mathrm{~min}$. at $90^{\circ} \mathrm{C}$, rinsed, washed with water, acidified by immersing in $\mathrm{HCl}(1 \%)$ for 4 min, and then stained with a mixture of chlorazol black E $0.03 \%$ (CBE), lactic acid, glycerol (1:1:1), for $15 \mathrm{~min}$ at $90^{\circ} \mathrm{C}$. Root segments randomly chosen and examined under the light microscope $(40 \times$ magnification) for presence of mycorrhizal structures (hyphae, arbuscules and/or vesicles) (Bouamril et. al., 2006).

\section{Extraction and counting of VAM Spores}

After two month of cultivation, spores of VAM in all treatments were isolated from rhizosphere using a mix of wet-sieving and sucrose gradient techniques (Brundrett et al., 1996). $100 \mathrm{~g}$ of rhizosphere soil was rinsed in through 1000, 500, 250, 106 and $45 \mu \mathrm{m}$ sieves; soil was recovered from $45 \mu \mathrm{m}$ sieve, suspended in water, and centrifuged at $3000 \mathrm{rpm}$ for $3 \mathrm{~min}$. The supernatant was discarded and the soil sediment was resuspended in a sucrose solution (60\%) and centrifuged at $1000 \mathrm{rpm}$ for $2 \mathrm{~min}$. The supernatant containing spores was filtered under vacuum on filter paper (Whatman \# 1). The spores were counted using the light microscope ( $40 \times$ magnification), and the estimated number of spores was attributed to $250 \mathrm{~g}$ of soil.

\section{Bacterial count}

About two months after sawing, total bacterial count and spore forming bacteria count were performed to detect its differences among treatments as a result of biofertilizers and water regime. Total bacterial count, were determined by plate count method on nutrient soil extract agar medium (LMG medium 30: Agar 15g, yeast extract 2g, peptone $5 \mathrm{~g}, \mathrm{NaCl} 5 \mathrm{~g}$, Lab. Lemco beef extract 1g, soil extract $1 \mathrm{~L}, \mathrm{pH} 7.2$ at $25^{\circ} \mathrm{C}$ in $1 \mathrm{~L}$ of tap water) with incubation at $30^{\circ} \mathrm{C}$ for $48 \mathrm{~h}$ (Jacobs and Gerstein, 1960). Count of spore forming bacteria, were carried out by plating the same medium but after heating the serial dilutions at temperatures $80^{\circ} \mathrm{C}$ for 15 minutes with incubation at $30^{\circ} \mathrm{C}$ for $48 \mathrm{~h}$ (Clark, 1965).

\section{Statistical analyses:-}

The collected data were subjected to combined analysis of variance (ANOVA) of split plot design (Gomez and Gomez, 1984). Levene test (1960) was run prior to the combined analysis to test the homogeneity of individual error terms. Least significant difference (LSD) test was used to detect the significant differences among means at 0.05 probability levels.

\section{Results and Discussion}

\section{Bacteria and mycorrhizae within potato crop root zone:-}

Examination of AM fungi infection by root staining revealed the presence of different mycorrhizal structures (hyphae, arbuscules and vesicles) in all selected samples. Table (3) shows counts 
of total and spore forming bacteria (TB and SFB) and mycorrhizal spores (MS) count $/ 250 \mathrm{~g}$ soil. In general, TB counts were relatively closed to each other's, while variations occurred in the count of SFB especially in control treatment which was very low in all irrigation levels. This could be explained by the changes occurred in the bacteria species and other microorganism as a consequential of added Biogen, Mycorrhizae within different studied irrigation levels. Various studies have followed how the presences of MF influence the microbial community (Hodge, 2014). Herman et al. (2012) and Nuccio et al., (2013) mentioned that when AMF grow into organic litter patches, the microbial community structure is changed and stimulates decomposition and transfer $\mathrm{N}$ to the plants. Another study showed that experimental evidence exists for hyphal exudates of AM fungi having a pronounced effect on soil bacterial community composition belong with some members of Enterobacteriaceae being particularly strongly promoted otherwise, there are microorganisms identified as "mycorrhiza helper bacteria" which upon co-inoculation with the AM fungi increase the colonization rates of the host roots (Ma et al., 2018), which agrees with our finding that showed an increase of MS counts under Biogen treatment although there is no treatment with AMF when compared with control. Arbuscular mycorrhizal fungi interactions with free-living bacteria have been documented by Khalid et al. (2017) who reported that the synergy between AMF (Glomus fasciculatum, G. mosseae) and PGPB (Azotobacter chroococcum, Bacillus mucilaginouss and B. megaterium) increased root colonization of spinach by AMF. It has long been known that spore germination can be stimulated by soil microorganisms, from Actinobacteria to Pseudomonads, although the most relevant role is played by bacteria living in intimate association with AMF often located on and within spore wall layers (mycorrhizospheric bacteria) (Giovannini et al., 2020).

Table 3: Effect of bioinoculation added and water levels on count of bacteria and mycorrhizae spores in soil within roots zone.

\begin{tabular}{cccccc}
\hline $\begin{array}{l}\text { Treatments } \\
\text { Bio fertilizer }\end{array}$ & $\begin{array}{c}\text { Levels } \\
\text { \% }\end{array}$ & $\begin{array}{c}\text { Total bacterial } \\
\text { count }\end{array}$ & $\begin{array}{c}\text { Spore forming } \\
\text { Bacteria count }\end{array}$ & $\begin{array}{c}\text { Mycorrhizal } \\
\text { spores } \\
\text { count/250g soil }\end{array}$ & $\begin{array}{c}\text { Mycorrhizal spores } \\
\text { count /plant dry } \\
\text { weight (g) }\end{array}$ \\
\hline Control & 60 & $73 \times 10^{4}$ & $180 \times 10^{2}$ & 26 & 9.0 \\
& 80 & $69 \times 10^{5}$ & $335 \times 10^{2}$ & 95 & 70.9 \\
\hline & 100 & $42 \times 10^{5}$ & $200 \times 10^{2}$ & 54 & 23.2 \\
\hline Mycorrhizaen & 60 & $110 \times 10^{4}$ & $95 \times 10^{4}$ & 931 & 25.2 \\
& 80 & $78 \times 10^{5}$ & $50 \times 10^{6}$ & 6100 & 154.8 \\
\hline Biogen & 100 & $34 \times 10^{5}$ & $76 \times 10^{4}$ & 3350 & 77.9 \\
\hline Mix (50\% & 60 & $56 \times 10^{4}$ & $255 \times 10^{2}$ & 200 & 1.1 \\
Mycorrhizaen & 100 & $93 \times 10^{4}$ & $45 \times 10^{4}$ & 1680 & 0.5 \\
$+\mathbf{5 0 \%}$ Biogen) & 80 & $87 \times 10^{4}$ & $134 \times 10^{3}$ & 660 & 1.0 \\
\hline & 100 & $201 \times 10^{4}$ & $80 \times 10^{4}$ & 39 & 107.9 \\
\hline
\end{tabular}

Results showed that Mycorrhizae at $80 \%$ irrigation level recorded the highest count of MS, SFB and Mycorrhizal spores count / plant dry weight (g), followed by mix treatment at water level $100 \%$. These results indicated that water levels have a direct effect on bacteria and mycorrhizae count. These results being coincide with those obtained by Simpson and Daft (1990) who inoculated Maize (Zea mays) and sorghum (Sorghum bicolor) with a range of VAM fungi and grown under water-stressed and unstressed conditions, spore production from most inocula was reduced by water-stress, both in total spore numbers and in terms of spores per gram plant weight. Giovannini et al. (2020) noticed that, a key fungal characteristic directly linked to AMF establishment and persistence in the field is represented by spore germination, which is affected by different factors including soil moisture, which may influence the different steps of mycorrhizal establishment, from spore germination to appressorium formation and intraradical growth. Deficit irrigation can reduce AM fungus root colonization, but the inoculation of efficient fungi may help enhancing colonization and consequently population of AM fungi in this environment (Volpato et al., 2020). Also, Ghorbany et al. (2019) indicate that, application of investigated bio-fertilizers was not beneficial in drought stress condition this result based on the results of means comparison analysis with the interaction of severe drought stress $(200 \mathrm{~mm}) \times$ control, severe drought stress $\times$ Mycorrhiza, and severe drought stress $\times$ Rhizobium bio-fertilizers, and they 
concluded that, Proper water management is a critical parameter in bio-fertilizer inoculation studies. Also results revealed that the irrigation water at $100 \%$ resulted in a reduction of bacteria and mycorrhizae count. This may be due to oxygen also has a dramatic impact on microbial activity in poorly soil aeration due to excess water (Manitoba, 2013).

\section{Soil nutrient availability:-}

Nutrient availability in the soil is among the most important factors affecting plant growth and yield production. Hence, the role of biological fertilization on the enhancement of soil nutrient availability can be very economically and environmentally advantageous. Data in Table (4) indicate that the availability of soil nutrient (N, P and K) significantly affected by all the treatments under study.

Data show that, using biofertilizers either Mycorrhizae or Biogen or the mix of them significantly increased the percentage of available $\mathrm{N}, \mathrm{P}$ and $\mathrm{K}$ in the soil compared without inoculation treatment. Such results is in agreement with that obtained by Miransari (2013) who indicate that application of biofertilization, can efficiently affect the availability of soil nutrients and hence plant growth and that can be happen by different mechanisms such as mineralization of soil organic matter, interacting with other soil microbes as well as production of different biochemicals such as plant hormones and enzymes. Gendy et al. (2013) ascribed the superiority of the application of bio-fertilizers Mycorrhizae and Biogen due to microbiological processes that can change unavailable forms of nutrients into available ones that can be easily assimilated by plants, it enable to release the fixed nitrogen, hence increasing the concentration and availability of this element in root zone. Fawzy et al. (2012) recorded the highest amounts of N,P and K \% by using 100\% mineral fertilizer with bio fertilizer (Biogen), On the contrary, the lowest amount of N, P and K \% of sweet pepper tissues were recorded by using $100 \%$ organic manure without bio fertilizer in the two seasons of study. Also, Ma et al., (2018) mentioned that there was an increase in the rates of mineralization of $\mathrm{N}$ bound in plant residues in the presence of an AM fungus. Ghorbany et al. (2019) indicated that, the biological activity of these beneficial microorganisms can increase the availability of nutrients and also helps to enhance the soil health and subsequently lead to increase of soil fertility.

It can be deduced from the data that Mycorrhizae was more efficiently affect the availability of P\% than Biogen. This result agree with a number of studies have demonstrated the ability of arbuscular mycorrhizal fungi to solubilize insoluble nutrients. This has been mainly ascribed to the fact that mobilizes phosphorus directly from organic matter through the excretion of phosphatases or from minerals through the excretion of organic acids (Frey-Klett et al., 2015). Meanwhile, most phosphate in soils is in the form of ortho-phosphate, which cannot be directly utilized by plants, AMF can secrete enzymes that hydrolyze organic $\mathrm{P}$ compounds in soil (Ma et al., 2018). The mycorrhizal phosphatase enzyme activity converts phosphate into soluble forms and enables mycorrhizal plants to take up more phosphorus than non-mycorrhizal plants and it has been demonstrated that the extraradical hyphae of Glomus intraradices were readily capable of hydrolyzing exogenously supplied organic phosphorus sources and transferring significant quantities of phosphorus to roots (Garcia and Racsko, 2018).

Data also show that irrigation levels have a clear effect on nutrient availability in the soil. The highest values of the nutrient availability (N, P and K\%) in the soil were realized at $80 \%$ irrigation level compared to 60 and $100 \%$ irrigation levels. This may be owing to the fact that when the soil moisture decreases, the availability of nutrients in the soil is lowered because irrigation water important for dissolve soil nutrients (soil solution) which available for plant uptake, while in case of increasing irrigation level this could be attributed to poorly soil aeration due to excess water or compaction, some of the soil microbes will switch to anaerobic respiration and use alternatives to oxygen $\left(\mathrm{O}_{2}\right)$ to breathe, some of these alternatives to $\mathrm{O}_{2}$ include plant available nitrate $\left(\mathrm{NO}_{3}^{-}\right)$that is converted to gases and lost to the atmosphere as called denitrification or nutrients can be lost by leaching (Manitoba, 2013). Microbial decomposition is greatest at moisture contents near field capacity because at field capacity, soils tend to provide a balance of both air and water, nevertheless, it tends to be slower in case of insufficient soil aeration, thereby, proper irrigation level increase the population of bacteria and mycrohizae and its activity this in turn increase releasing available nutrients in the soil (Bhattarai et al., 2010).

In according the interaction of irrigation levels and biofertilizer inoculation the percent of available $\mathrm{N}$ in the soil was high at Biogen inoculation associated with $80 \%$ irrigation level may be due to the ability of Biogen to fix $\mathrm{N}$ especially at this level of irrigation. Otherwise, inoculation with 
Mycorrhizae at $80 \%$ irrigation level gave high $\mathrm{P} \%$ and $\mathrm{K} \%$ in the soil. These results maybe because $80 \%$ irrigation level can be a suitable condition to enhance the effect of this microbial inoculations.

Table 4: Effect of bioinoculation added and irrigation levels and their interaction on soil nutrients availability.

\begin{tabular}{|c|c|c|c|c|c|}
\hline \multirow{2}{*}{ Treatments } & & \multicolumn{4}{|c|}{ Soil available nutrients } \\
\hline & & \multirow{2}{*}{$\begin{array}{l}\mathbf{N} \\
0.012\end{array}$} & \multicolumn{2}{|c|}{$\mathbf{P}$} & $\mathbf{K}$ \\
\hline \multirow{3}{*}{ Irrigation Levels \% } & 60 & & 0.054 & $\mathrm{~B}$ & $1.75 \mathrm{~B}$ \\
\hline & 80 & $0.020 \mathrm{~A}$ & 0.063 & A & $3.33 \mathrm{~A}$ \\
\hline & 100 & $0.014 \mathrm{E}$ & 0.063 & $\mathrm{~A}$ & $1.98 \mathrm{~B}$ \\
\hline \multirow{4}{*}{ Bio-fertilizer } & Control & $0.013 \mathrm{E}$ & 0.057 & $\mathrm{C}$ & $1.57 \mathrm{~B}$ \\
\hline & Biogen & $0.019 A$ & 0.060 & $\mathrm{~B}$ & $3.13 \mathrm{~A}$ \\
\hline & Mycrrohizaen & $0.016 \mathrm{~A}$ & 0.067 & A & $3.37 \mathrm{~A}$ \\
\hline & Mix & $0.013 \mathrm{E}$ & 0.056 & $\mathrm{C}$ & $1.33 \mathrm{~B}$ \\
\hline \multirow{12}{*}{ Interaction } & $60 *$ Control & $0.013 \mathrm{c}$ & 0.050 & $\mathrm{c}$ & $1.10 \mathrm{e}$ \\
\hline & $80 *$ Control & $0.014 \mathrm{c}$ & 0.060 & $\mathrm{~b}$ & $1.90 \mathrm{c}$ \\
\hline & 100* Control & $0.013 \mathrm{c}$ & 0.060 & $\mathrm{~b}$ & $1.70 \mathrm{~d}$ \\
\hline & $60 *$ Biogent & $0.012 \mathrm{c}$ & 0.060 & $\mathrm{~b}$ & $1.30 \mathrm{e}$ \\
\hline & $80 *$ Biogen & $0.030 \mathrm{a}$ & 0.060 & $\mathrm{~b}$ & $2.80 \mathrm{c}$ \\
\hline & $100 *$ Biogen & $0.014 \mathrm{c}$ & 0.060 & $\mathrm{~b}$ & $3.80 \mathrm{~b}$ \\
\hline & $60 *$ Mycrrohizaen & $0.013 \mathrm{c}$ & 0.060 & $\mathrm{~b}$ & $3.60 \mathrm{bc}$ \\
\hline & $80 *$ Mycrrohizaen & $0.020 \mathrm{~b}$ & 0.070 & $\mathrm{a}$ & $6.00 \mathrm{a}$ \\
\hline & $100 *$ Mycrrohizaen & $0.014 \mathrm{c}$ & 0.060 & $\mathrm{~b}$ & $2.00 \mathrm{~d}$ \\
\hline & $60 *$ Mix & $0.011 \mathrm{c}$ & 0.047 & $\mathrm{c}$ & $1.10 \mathrm{e}$ \\
\hline & $80 * \operatorname{Mix}$ & $0.014 \mathrm{c}$ & 0.060 & $\mathrm{~b}$ & $1.60 \mathrm{de}$ \\
\hline & $100 *$ Mix & $0.014 \mathrm{c}$ & 0.060 & $\mathrm{~b}$ & $1.30 \mathrm{e}$ \\
\hline
\end{tabular}

\section{Dry -sieved aggregates:-}

The dry sieving aggregates values are shown in Table (5). Data reveal that, the dry stable aggregates (D.S.A\%) which having diameters from 1 to $0.5 \mathrm{~mm}$ were found to be the largest size presented in the different studied treatments.

Table 5: Effect of bioinoculation added and irrigation levels on distribution fraction (\%) of soil dry sieved aggregates.

\begin{tabular}{|c|c|c|c|c|c|c|c|}
\hline \multirow{4}{*}{ Bio-fertilizer } & \multicolumn{7}{|c|}{ Irrigation Levels } \\
\hline & \multicolumn{7}{|c|}{$60 \%$} \\
\hline & \multicolumn{7}{|c|}{ Dry aggregates Diameter $(\mathrm{mm})$} \\
\hline & $10-2$ & $2-1$ & $1-0.5$ & $0.5-0.25$ & $0.25-0.125$ & $\begin{array}{c}0.125- \\
0.063\end{array}$ & $<0.063$ \\
\hline Control & 14.1 & 9.6 & 37.9 & 30.4 & 7.00 & 0.89 & 0.11 \\
\hline Biogen & 15.6 & 8.7 & 36 & 30.9 & 7.40 & 1.17 & 0.23 \\
\hline Mycrrohizaen & 11.9 & 8.7 & 39.1 & 33.4 & 6.26 & 0.29 & 0.35 \\
\hline \multirow[t]{2}{*}{ Mix } & 9.6 & 15.5 & 41.9 & 26.6 & 5.3 & 0.92 & 0.18 \\
\hline & \multicolumn{7}{|c|}{$80 \%$} \\
\hline Control & 14.94 & 16.6 & 38.9 & 25.6 & 3.4 & 0.4 & 0.16 \\
\hline Biogen & 14.5 & 14.35 & 40.7 & 24.98 & 4.72 & 0.65 & 0.1 \\
\hline Mycrrohizaen & 11.15 & 10.6 & 35.7 & 34.27 & 7.16 & 0.88 & 0.24 \\
\hline \multirow[t]{2}{*}{ Mix } & 15.1 & 16.01 & 35.05 & 30.2 & 3.00 & 0.6 & 0.04 \\
\hline & \multicolumn{7}{|c|}{$100 \%$} \\
\hline Control & 16.65 & 14.40 & 33.5 & 29.16 & 5.66 & 0.56 & 0.07 \\
\hline Biogen & 16.96 & 10.9 & 35.95 & 31.55 & 2.5 & 2.1 & 0.05 \\
\hline Mycrrohizaen & 18.7 & 9.22 & 35.4 & 29.9 & 6.59 & 0.94 & 0.15 \\
\hline Mix & 16 & 11.4 & 35.4 & 29.2 & 6.9 & 0.98 & 0.12 \\
\hline
\end{tabular}

Furthermore, the percentages of other sizes of dry stable aggregates decrease as their diameters decrease, whereas the lowest values exist in case of the aggregates having diameters less than 0.063 $\mathrm{mm}$. Results showed that, the inoculation resulted in the highest increase of (D.S.A\%) at diameters 1- 
0.5 and $0.5-0.25 \mathrm{~mm}$, compared to without inoculation. These may be as a result to the inoculation increase soil aggregation and aggregates stability this effect can be attributed hereby to the microbial activity which in turn increase aggregate stabilizing factor. Especially, inoculation with Mycorrhiza resulted in the highest increase (D.S.A\%) at the diameters $0.5-0.25 \mathrm{~mm}$ under all studied irrigation levels. This result in harmony with Ma et al. (2018) who mentioned that AMF enhance ecosystem sustainability by influencing numerous soil properties and structure including soil stability, storage, soil moisture and nitrogen $(\mathrm{N}), \mathrm{C}$ and phosphorus $(\mathrm{P})$ cycles. Mycorrhizae play a major role in the soil particle aggregation process and contribute to improving soil structure which leads to better water infiltration, better aeration, less erosion and leaching this result due to the emanating fungal mycelium improves soil aggregation thus, modify soil structure (Frey-Klett et al., 2015). Furthermore AMF produce large amounts of insoluble glycoprotein, glomalin and polysaccharides, which contribute to aggregate stability (Ma et al., 2018).

\section{Vegetative growth parameters:-}

Data in table (6) show the values of growth parameters (plant height, number of leaves per plant, fresh and dry weight of plant, leaf area of plant and chlorophyll content) affected by bio-fertilizer inoculation and irrigation levels under studying.

It can be observe from the data that biofertilizer inoculation enhanced the growth parameters than control. The superiority of bio-fertilizers for stimulating plant fresh and dry weight owing to the favorable effect on plant growth and yield that may be attributes to the improve nutrition and production of growth promoting substances by micro-organisms especially by the increment of $\mathrm{N}$ in the root zone as a result of fixed $\mathrm{N}$, nitrogen can enhance protein synthesis, division and enlargement of cells as well as stimulates photosynthesis processes (Gendy et al., 2013).

Although, inoculation with Mycorrhizae or Biogen or mix of them have appositive effect on enhancing plant growth compared with the absence of the inoculation but this effect were significantly different between the treatments. Inoculation with AMF more effective in improving plant growth parameters than the Mix except plant height there was no significant differences between of them. While inoculation with biogen only has the lowest effect of plant growth under study compared with the AMF or the mix of them. This finding agrees with that concluded by Lone et al. (2015) who indicated that, the chlorophyll content besides morphological growth parameters and fresh and dry weight content of both cultivars of potato plant are shown to present in higher level in the mycorrhizae infected as compared to the non-inoculated ones. Moreover, Susiana et al.(2019) found that mycorrhizal application significantly increased height, the number of leaf. This mainly rendered to mycorrhizal fungi synthesise different phytohormones, especially indole-3-acetic acid (IAA), which is involved in the formation and the functioning of the ectomycorrhizal symbiosis, which can mediate plant growth promotion (Frey-Klett et al., 2015).

There was a significant difference between the values of growth parameters with added different irrigation levels. The highest value was obtained under $80 \%$, while the lowest values were under $60 \%$ irrigation level. Meanwhile, irrigation level at $100 \%$ was in between of them. Irrigation level at $80 \%$, stimulated plant growth and elongation as compared with $100 \%$ and $80 \%$ these may be due to that, this level of water achieved adequate of water for the plant growth. Sufficient soil moisture is a deciding parameter for plant growth, in critical developmental phases, both under- and oversupply can have a negative impact on agricultural crop yields, over the last 40 years, soil moisture levels during the growing season have significantly declined, on both light and heavy soils (Anita and Beste, 2020). It becomes ever clearer that the supply of $60 \%$ from irrigation make plant undergoes water deficit due to water limitation in the plant roots area which resulted in lower water absorption. Water deficit in plant may lead physiological disorders, such as a reduction in photosynthesis and transpiration (AbdelKader et al., 2014). On the other hand, at $100 \%$ irrigation level increased the water around the plant that can cause unsuitable conditions of aeration to the respiration of plant root. Consequently, these conditions might disturb biochemical and physiological processes, hence resulted in morphological changes of the plant and effect on plant growth (Kandowangko et al., 2009). The interaction between irrigation levels and inoculation also have a significant effect, the obtained results observe that, the microbial inoculation has strong effect upon irrigation levels treatments on the plant growth that even with the low irrigation level under study (60\%). 
Table 6: Effect of bioinoculation added and irrigation levels on some growth parameters of potato plants.

\begin{tabular}{|c|c|c|c|c|c|c|c|}
\hline \multicolumn{2}{|c|}{ Treatments } & $\begin{array}{c}\text { Plant } \\
\text { height } \\
\text { cm }\end{array}$ & $\begin{array}{c}\text { Number } \\
\text { of leaves } \\
\text { plant }^{-1}\end{array}$ & $\begin{array}{c}\text { Plant } \\
\text { fresh } \\
\text { weight }(g)\end{array}$ & $\begin{array}{l}\text { Plant } \\
\text { dry weight } \\
\text { (g) }\end{array}$ & $\begin{array}{c}\text { Leaf } \\
\text { area } \\
\text { plant }^{-1} \mathrm{~cm}^{2}\end{array}$ & $\begin{array}{c}\text { Chlorophyll } \\
\text { content } \\
\text { (spade) }\end{array}$ \\
\hline Irrigation & 60 & $28.7 \mathrm{C}$ & $18.9 \mathrm{C}$ & $151.2 \mathrm{C}$ & $36.4 \mathrm{C}$ & $105.4 \mathrm{C}$ & $36.7 \mathrm{C}$ \\
\hline Levels & 80 & 35.8 & $24.0 \mathrm{~A}$ & $187.4 \mathrm{~A}$ & $43.8 \mathrm{~A}$ & $134.9 \mathrm{~A}$ & 40.1 \\
\hline$\%$ & 100 & $31.4 \mathrm{~B}$ & $21.4 \mathrm{~B}$ & $166.4 \mathrm{~B}$ & $39.5 \mathrm{~B}$ & $125.3 \mathrm{~B}$ & $38.4 \mathrm{~B}$ \\
\hline \multirow{4}{*}{ Bio-fertilizer } & Control & $19.2 \mathrm{C}$ & $12.9 \mathrm{D}$ & $126.0 \mathrm{D}$ & $24.7 \mathrm{D}$ & $84.4 \mathrm{D}$ & 29.4 \\
\hline & Biogen & $31.7 \mathrm{~B}$ & $21.5 \mathrm{C}$ & $162.8 \mathrm{C}$ & $39.8 \mathrm{C}$ & $120.6 \mathrm{C}$ & 35.9 \\
\hline & Mycrrohizaen & $39.7 \mathrm{~A}$ & $26.9 \mathrm{~A}$ & 203.6 & $49.7 \mathrm{~A}$ & $150.7 \mathrm{~A}$ & $44.9 \mathrm{~A}$ \\
\hline & Mix & $37.3 \mathrm{~A}$ & $24.5 \mathrm{~B}$ & $180.9 \quad \mathrm{~B}$ & $45.2 \mathrm{~B}$ & $131.9 \mathrm{~B}$ & $43.4 \mathrm{~B}$ \\
\hline \multirow{12}{*}{ 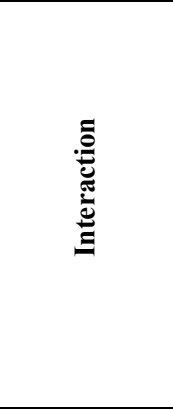 } & $60 *$ Control & $17.3 \mathrm{i}$ & $11.3 \mathrm{~h}$ & $110.2 \mathrm{~h}$ & $22.1 \mathrm{k}$ & $72.6 \mathrm{k}$ & 27.8 \\
\hline & $80 *$ Control & $21.4 \mathrm{gh}$ & $14.6 \mathrm{~g}$ & $145.6 \mathrm{f}$ & $28.4 \mathrm{j}$ & $92.4 \mathrm{i}$ & $31.1 \mathrm{~h}$ \\
\hline & 100* Control & 19.0 hi & $12.8 \mathrm{~h}$ & $122.1 \mathrm{~g}$ & $23.7 \mathrm{k}$ & $88.2 \mathrm{j}$ & $29.4 \mathrm{i}$ \\
\hline & $60 *$ Biogent & $28.8 \mathrm{f}$ & $18.8 \mathrm{f}$ & $146.3 \mathrm{f}$ & $36.9 \mathrm{i}$ & $103.7 \mathrm{~h}$ & 34.5 \\
\hline & $80 *$ Biogen & $35.7 \mathrm{~d}$ & $24.4 \mathrm{~cd}$ & $179.4 \mathrm{~cd}$ & $43.0 \mathrm{fg}$ & $132.0 \mathrm{~d}$ & 37.6 \\
\hline & $100 *$ Biogen & 30.8 ef & $21.3 \mathrm{e}$ & $162.8 \mathrm{ef}$ & $39.4 \mathrm{~h}$ & $126.0 \mathrm{f}$ & $35.7 \mathrm{fg}$ \\
\hline & $60 *$ Mycrrohizaen & $36.0 \mathrm{~cd}$ & $23.5 \mathrm{~d}$ & 182.9 & $46.2 \mathrm{de}$ & 129.6 & $43.1 \mathrm{bc}$ \\
\hline & 80*Mycrrohizaen & $44.6 \mathrm{a}$ & $30.5 \mathrm{a}$ & 224.2 & $53.8 \mathrm{a}$ & 165.0 & $47.0 \mathrm{a}$ \\
\hline & $100 *$ Mycrrohizaen & 38.4 & $26.6 \mathrm{~b}$ & $203.6 \mathrm{~b}$ & $49.3 \mathrm{c}$ & 157.5 & $44.7 \mathrm{~b}$ \\
\hline & $60 *$ Mix & $32.9 \mathrm{e}$ & $21.9 \mathrm{e}$ & $165.2 \mathrm{e}$ & $40.3 \mathrm{~g}$ & 115.9 & 41.6 \\
\hline & $80 *$ Mix & $41.5 \mathrm{~b}$ & $26.6 \mathrm{~b}$ & $200.6 \mathrm{~b}$ & $49.9 \mathrm{bc}$ & $150.0 \mathrm{c}$ & $44.7 \mathrm{~b}$ \\
\hline & $100 * M i x$ & $37.6 \mathrm{c}$ & $25.0 \mathrm{bc}$ & $177.0 \mathrm{~d}$ & $40.3 \mathrm{~g}$ & $129.6 \mathrm{e}$ & 43.9 \\
\hline
\end{tabular}

* Similar letters indicate nonsignificant at 0.05 levels.

This results agree with Kandowangko et al. (2009) who found a reduction in ABA content in droughted plant inoculated by AMF may be due to hypha which assists plant to extract water and essential nutrients under dry conditions and also due to the increase of nutrient status of the host plants especially during drought conditions and it was able to stimulate the activation of principle enzymes that involve in nitrogen assimilation such as nitrate reductase and glutamate synthetase, the improvement of this enzyme activity can change and increase nitrogen content of the plant which resulted in increase of proline content, consequently, this situation can improve plant adaptability to drought stress and plant recovery soon after rewatering, on the contrary, the plants without inoculation showed severe stress due to drought, also they explain that, this results suggested that inoculation of AMF to the drougted plant is able to alleviate the strained by manipulation of stomatal conductance so that the stomata are still remained open for the longer period. Also, it can be noticed the enhancing effect of Biogen on plant growth under low irrigation level this result agree with Gendy et al. (2013) who indicated that bio-fertilizers treatment by biogen increases growth characters compared to control, the superiority of bio-fertilizers biogen for stimulating plant fresh and dry weight owing to the favorable effect of biogen on plant growth and yield attributes might be due to the improved nutrition and production of growth promoting substances by micro-organisms especially by the increment of $\mathrm{N}$ in the root zone as a result of fixed $\mathrm{N}$ by bacteria in Biogen. Also mix inoculation AMF and Biogen and $60 \%$ irrigation level exhibited an enhancement role with low irrigation level on plant growth. Such finding is similar to that found Kandowangko et al. (2009) who indicated that the inoculums of Azospirillum sp. and AMF can work synergically and was able to improve proline content and reduce ABA concentration in the corn plant subjected to drought stress during flowering and seed filling. Beside the beneficial effect of the biofertilizers under study on improves soil aggregation which leads to maintain soil moisture, better water infiltration, better aeration and less leaching in the soil.

This progressive effect of the inoculation on plant growth was optimizing at $80 \%$ irrigation level. The results pointed that the tallest plants, highest number of leaves and leaf area, heaviest plant fresh or dry weights beside the highest concentrations of chlorophyll content were obtained from applying the water at the level of $80 \%$ with adding AMF Colonization. Followed by inoculation with mix AMF and Biogen associated with $80 \%$ irrigation level. This result are in keeping with Ghorbany et al. (2019) who demonstrated that, application of Mycorrhiza biofertilizer in normal irrigation condition is more hopeful for plant growth. 


\section{Tuber yield and quality component of potato crop:-}

Data presented in table (7) reveal that there are significant differences in the potato tuber yield quantity and quality associated with microbial inoculants treatments. It can be note from the data that, without inoculation treatment resulted in a significantly lower yield of both quantity and quality. The superiority of the bio fertilizer of Biogen and Microhizae on enhancing the potato tuber yield quantity and quality that may be due to the release of the fixed nitrogen and increasing the concentration and availability of the essential elements in the root zone that can enhances plant growth and the yield. This result are agree with Fawzy et al. (2012) who interpreted that bio-fertilizer inoculation helps to meet nitrogen requirement besides nitrogen fertilizer and other plant growth substances resulting in good yield. Many investigators had a similar trend of these results which support the present data Hosseny and Ahmed (2009) reported that, the increases in yield in lettuce plants related to bio-fertilizer biogen due to the beneficial effects of the bacterial not only due to their $\mathrm{N}$ fixation capacity, but also because of their ability to produce growth hormones and siderophores. Fawzy et al. (2012) indicated that, using Biogen significantly increased the total yield of sweet pepper fruits due to increase the levels of extractable NPK or micro-nutrients which subsequently increased plant growth and yield. Gendy et al. (2013) revealed that biogen treatment have a considerable effect on growth and yield of guar plants during both seasons compared with untreated plants, they ascribed that due to the increase in biological fixation nitrogen as well as growth promoting substances such as indole acetic acid, cytokinins and gibberellins produced by the organisms used.

While presented data revealed that, AMF resulted in significantly higher values of the tuber yield per plant (kg) expressed as a weight, tuber firmness and tuber volume (liter/ten tubers) followed by Mix inoculation and followed by Biogen. This finding agrees with Lone et al. (2015) who emphasized that the inoculation of AMF significantly stimulated production of potato tubers, by affecting in hormone balance in potato plants leading to increased initiation and production of tubers. Such promoting effect of AMF on potato tubers was observed by Deja-Sikora et al. (2020) who demonstrated that, the potential yield benefits of inoculation of potatoes with AM fungi, that may be due to AMF facilitate the uptake and transfer of mineral nutrients such as phosphorus $(\mathrm{P})$, nitrogen $(\mathrm{N})$, sulfur, potassium, calcium, copper and zinc, from the soil to their host plants by means of the extraradical mycelium extending from colonized roots into the soil, furthermore, colonization with AMF was linked to the lower incidence of infection with some potato pathogens or reduced disease. Additionally, the enhancement of water, P and other nutrients uptake of AM fungi colonized plants (Kandowangko et al., 2009 and Crespo, 2015). Furthermore, AMF access to either inorganic or organic soil nitrogen that can improving nitrogen nutrition of their plant host also, AMF symbiosis modifies root morphology by promoting root branching for host plant in addition, root exudation in the mycorrhizosphere is quantitatively and qualitatively different from that in the rhizosphere because mycorrhizal fungi use some of the root exudates and modify the root metabolic functions, furthermore, mycorrhizal fungi associated with plant roots can produce antibiotics ( Frey-Klett et al., 2015).

In regard to the effect of the studied irrigation leldvels. It is obviously from the data in table (7) and Fig. (1) that irrigation level at $80 \%$ gives the highest values of the weight of tuber yield per plant $(\mathrm{kg})$, tuber firmness and tuber volume (liter/ten tubers). While $100 \%$ irrigation level although gives the highest number of tuber per plant but that affected on the yield quality by increasing the unmarketable yield per plant as weight or number. On the other hand $60 \%$ irrigation level appeared the lowest yield and quality. The interpretation of these results may be due to that, adequate water accelerate the physiological processes and favors the mineral uptake and translocation of metabolizes, which in turn increases the yield quantity and quality but the insufficient water supply to a crop during critical stages of growth causes substantial yield loss and low quality. Similarly, increasing water causes unsuitable conditions of aeration to the respiration of plant root. These results are agreed with Vale et al. (2007) they indicated that potato is more sensitive to drought than some other crops and the physiological processes associated with drought tolerance are less understood than for other crop species. Also this condition can be unsuitable for microbial presence and its effect too. Proper irrigation level increase the population of bacteria and this in turn increase nitrogen fixation and release of phytohormones and trace elements lead to increase plant growth (Ghorbany et al., 2019).

Concerning the influence of the interaction of the studied irrigation levels and bioinoculation. Studied microbial inoculation promoted the potato yield quality and quantity under low irrigation level $(60 \%)$ compared with this level of irrigation without inoculation. 
Table 7: Effect of bioinoculation added and water levels and their interaction on tuber quality and yield component of potato crop.

\begin{tabular}{|c|c|c|c|c|c|c|c|}
\hline \multicolumn{2}{|l|}{ Treatments } & \multirow{2}{*}{$\begin{array}{l}\begin{array}{l}\text { Tuber yield } \\
\text { plant }^{-1} \text { (kg) }\end{array} \\
473.8 \mathrm{C}\end{array}$} & \multirow{2}{*}{$\begin{array}{c}\begin{array}{c}\text { Tuber } \\
\text { number } \\
\text { plant }^{-1}\end{array} \\
15.3 \mathrm{~B}\end{array}$} & \multirow{2}{*}{$\begin{array}{c}\text { Unmarketable } \\
\begin{array}{c}\text { yield plant } \\
\text { (kg) }\end{array}\end{array}$} & \multirow{2}{*}{$\begin{array}{c}\begin{array}{c}\text { Unmarketa } \\
\text { ble number } \\
\text { plant }^{-1}\end{array} \\
4.6 \mathrm{~B}\end{array}$} & \multirow{2}{*}{$\begin{array}{c}\begin{array}{c}\text { Tuber } \\
\text { firmness }\end{array} \\
1.7 \mathrm{C}\end{array}$} & \multirow[t]{2}{*}{$\begin{array}{c}\begin{array}{c}\text { Tuber } \\
\text { Volume } \\
\text { (liter/ten } \\
\text { tubers) }\end{array} \\
853 \mathrm{C}\end{array}$} \\
\hline Irrigation & 60 & & & & & & \\
\hline Levels & 80 & $663.9 \mathrm{~A}$ & $15.2 \mathrm{~B}$ & $25.8 \mathrm{~B}$ & $4.1 \mathrm{~B}$ & $2.1 \mathrm{~A}$ & $1393 \mathrm{~A}$ \\
\hline$\%$ & 100 & $605.0 \mathrm{~B}$ & $18.0 \mathrm{~A}$ & $29.2 \mathrm{~A}$ & $5.4 \mathrm{~A}$ & $1.8 \mathrm{~B}$ & $1095 \mathrm{~B}$ \\
\hline \multirow{4}{*}{ Bio-fertilizer } & Control & $519.1 \mathrm{D}$ & $14.6 \mathrm{C}$ & $19.1 \mathrm{D}$ & $4.1 \mathrm{C}$ & $0.8 \mathrm{D}$ & $763 \mathrm{D}$ \\
\hline & Biogen & $561.9 \mathrm{C}$ & $14.1 \mathrm{C}$ & $21.0 \mathrm{C}$ & $4.1 \mathrm{C}$ & $2.0 \mathrm{C}$ & $1123 \mathrm{C}$ \\
\hline & Mycrrohizaen & $649.3 \mathrm{~A}$ & $16.8 \mathrm{~B}$ & $29.0 \mathrm{~B}$ & $4.7 \mathrm{~B}$ & $2.5 \mathrm{~A}$ & $1270 \mathrm{~A}$ \\
\hline & Mix & $593.3 \mathrm{~B}$ & $19.1 \mathrm{~A}$ & $37.4 \mathrm{~A}$ & $5.8 \mathrm{~A}$ & $2.3 \mathrm{~B}$ & $1297 \mathrm{~B}$ \\
\hline \multirow{12}{*}{ •气气 } & $60 *$ Control & $475.7 \mathrm{k}$ & $12.3 \mathrm{f}$ & $12.0 \mathrm{~h}$ & $3.0 \mathrm{f}$ & $0.7 \mathrm{e}$ & $540 \mathrm{~h}$ \\
\hline & $80 *$ Control & $565.7 \mathrm{~g}$ & $14.3 \mathrm{~d}$ & $14.0 \mathrm{~g}$ & $3.0 \mathrm{f}$ & $0.9 \mathrm{e}$ & $1000 \mathrm{e}$ \\
\hline & $100 *$ Control & $516.0 \mathrm{hi}$ & $17.0 \mathrm{c}$ & $31.3 \mathrm{~d}$ & $6.3 \mathrm{~b}$ & $0.8 \mathrm{e}$ & $750 \mathrm{~g}$ \\
\hline & $60 *$ Biogent & $490.3 \mathrm{j}$ & $13.0 \mathrm{e}$ & $20.0 \mathrm{e}$ & $3.7 \mathrm{e}$ & $1.8 \mathrm{de}$ & $820 \mathrm{f}$ \\
\hline & $80 *$ Biogen & $603.0 \mathrm{e}$ & $11.7 \mathrm{~g}$ & $11.7 \mathrm{i}$ & $3.7 \mathrm{e}$ & $2.2 \mathrm{~cd}$ & $1400 \mathrm{~b}$ \\
\hline & 100*Biogen & $592.3 \mathrm{f}$ & $17.7 \mathrm{c}$ & $31.3 \mathrm{~d}$ & $5.0 \mathrm{c}$ & $1.9 \mathrm{~d}$ & $1150 \mathrm{~d}$ \\
\hline & $60 *$ Mycrrohizaen & 420.71 & $13.0 \mathrm{e}$ & $18.7 \mathrm{f}$ & $3.0 \mathrm{f}$ & $2.2 \mathrm{c}$ & $1000 \mathrm{e}$ \\
\hline & 80*Mycrrohizaen & $843.0 \mathrm{a}$ & $17.7 \mathrm{c}$ & $34.0 \mathrm{c}$ & $4.7 \mathrm{~d}$ & $2.8 \mathrm{a}$ & $1580 \mathrm{a}$ \\
\hline & $100 *$ Mycrrohizaen & $684.3 \mathrm{~b}$ & $19.7 \mathrm{~b}$ & $34.2 \mathrm{c}$ & $6.5 \mathrm{~b}$ & $2.4 \mathrm{bc}$ & $1230 \mathrm{c}$ \\
\hline & $60 * \operatorname{Mix}$ & $508.7 \mathrm{i}$ & $22.7 \mathrm{a}$ & $48.7 \mathrm{a}$ & $8.7 \mathrm{a}$ & $2.1 \mathrm{~d}$ & $1050 \mathrm{~d}$ \\
\hline & $\mathbf{8 0} * \mathbf{M i x}$ & $644.0 \mathrm{c}$ & $17.0 \mathrm{c}$ & $43.7 \mathrm{~b}$ & $5.0 \mathrm{c}$ & $2.5 \mathrm{~b}$ & $1590 \mathrm{a}$ \\
\hline & $100 *$ Mix & $627.3 \mathrm{~d}$ & $17.7 \mathrm{c}$ & $20.0 \mathrm{e}$ & $3.7 \mathrm{e}$ & $2.2 \mathrm{c}$ & $1250 \mathrm{c}$ \\
\hline
\end{tabular}

* Similar letters indicate nonsignificant at 0.05 levels.

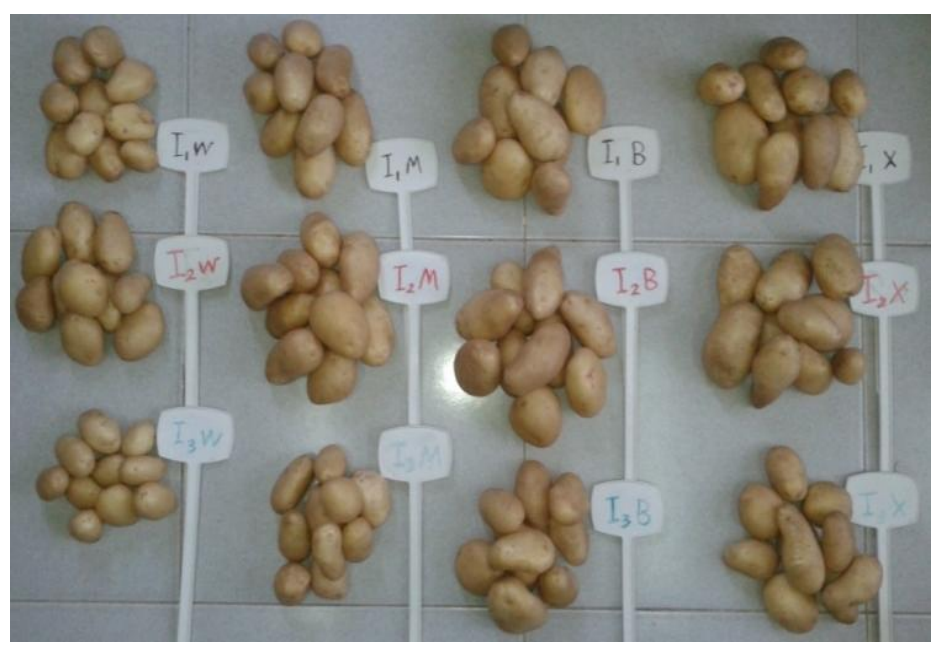

\{The characters of $I_{1}, I_{2}$ and $I_{3}$ appear the 60,80 and $100 \%$ of irrigation depletion levels respectively where the characters of $\mathrm{W}, \mathrm{M}, \mathrm{B}$ and $\mathrm{X}$ appear the bioinoculation fertilizers treatments of control, Mycrrohizaen, Biogen and Mix respectively\}

Fig. 1: Potato tuber performance related to irrigation depletion levels and bioinoculation fertilizers.

The use of inoculants is geared to enhance the root system, in turn increasing the overall surface area of that system for nutrient and water absorption. Beside the positive effect of this biofertilizers for enhancing soil aggregation which leads to maintain soil moisture, better water infiltration, better aeration, less leaching in the soil which reflect on the crop yield. These finding are supported by Lone et al. (2015)who recorded that AMF symbiosis have remarkable role in sustainable growth and development of plants as they help the land plants to acclimatize the biotic and abiotic conditions for their better survival, growth and development. As well as, Ma et al. (2018) manifested that AMF can help plants withstand drought. In addition, Garcia and Racsko (2018) stated that, the mycorrhizal plants resisted wilt for 36 to 48 hours longer than non-treated plants. Volpato et al. (2020) noted that, AM 
fungi can alleviate abiotic stress caused by low levels of $\mathrm{P}$ and/or a partially localized water deficit, plants thrive in water-limited conditions not only by increasing the supply of nutrients, but also by helping plants to resist water stress.

It is worthy to note that, the combined effect of $80 \%$ irrigation level and inoculation with AMF was recorded the highest values of quantity and quality of potato yield than other treatments followed by inoculation of mycorrhizal and $100 \%$ irrigation level, this improvement is attributed to consumption adequate and suitable amount of water to meet a high crop production beside the benefits of mycorrhiza contribute to optimize the yield. This result agree with Cosentino et al. (2007) who conclded that, using a suitable amount of water and good agricultural management may contribute substantially to the best use of water for crops and improving irrigation efficiency. Such result is in agreement with that obtained by Ghorbany et al. (2019) reported that, the combination of bio-fertilizers, such as Mycorrhiza, and Rhizobium, with proper water management could improve quantitative and qualitative traits of guar in South Khorasan province.

\section{Chemical constituents}

Available data in Table (8) show the chemical constituents of potato tuber yield obtained chlorophyll content, starch and total carbohydrates.

Data show that, either studied biofertilizers treatments or irrigation levels under study effect significantly on the content of chlorophyll, starch and total carbohydrates of the potato yield.

It is clear from the data that biofertilizer inoculation by Microhiza or Biogen or mix of them promoted the content of chlorophyll, starch and total carbohydrates of the potato yield. This result confirmed by Lone et al. (2015) who demonstrated that mycorrhizal fungi symbiosis lead to higher starch and reducing sugar contents than their comparable non-AMF potato plants. This can be attributed to major translocation of assimilates towards roots and tubers acting as sink that can emphasized its stimulatory effect on transferring carbohydrates from source to tubers through source-sink relationship than control. In other study on biogen biofertilizer Gendy et al. (2013) found that application of biofertilizers biogen leads to more total protein, total chlorophyll $(\mathrm{a}+\mathrm{b})$, total carbohydrate compared to the control.

Table 8: Effect of bioinoculation added and water levels and their interaction on tuber chemical content.

\begin{tabular}{|c|c|c|c|c|c|c|c|}
\hline \multicolumn{2}{|l|}{ Treatments } & \multicolumn{2}{|c|}{$\begin{array}{c}\text { Zhlorophyll content } \\
\text { (spade) }\end{array}$} & \multicolumn{2}{|c|}{$\begin{array}{c}\text { Starch } \\
\left(\mathrm{mg} \mathrm{100} \mathrm{g}^{-1}\right)\end{array}$} & \multicolumn{2}{|c|}{$\begin{array}{l}\text { Total carbohydrates } \\
\left({\left.\mathrm{mg} 100 \mathrm{~g}^{-1}\right)}^{\text {To }}\right.\end{array}$} \\
\hline Irrigation & 60 & 36.7 & $\mathrm{C}$ & 105.1 & $\mathrm{~B}$ & 5.2 & $\mathrm{C}$ \\
\hline Levels & 80 & 40.1 & $\mathrm{~A}$ & 111.3 & A & 5.8 & A \\
\hline$\%$ & 100 & 38.4 & B & 105.2 & B & 5.4 & $\mathrm{~B}$ \\
\hline \multirow{4}{*}{ Bio-fertilizer } & Control & 29.4 & $\mathrm{D}$ & 74.6 & $\mathrm{D}$ & 3.7 & $\mathrm{D}$ \\
\hline & Biogen & 35.9 & $\mathrm{C}$ & 102.0 & $\mathrm{C}$ & 5.3 & $\mathrm{C}$ \\
\hline & Mycorrhizaen & 44.9 & A & 127.4 & A & 6.6 & $\mathrm{~A}$ \\
\hline & Mix & 43.4 & $\mathrm{~B}$ & 124.7 & $\mathrm{~B}$ & 6.3 & $\mathrm{~B}$ \\
\hline \multirow{12}{*}{ 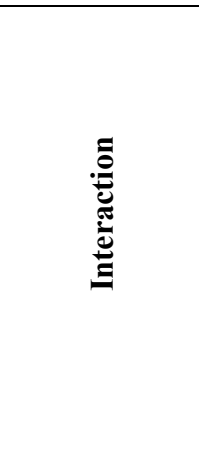 } & $60 *$ Control & 27.8 & $\mathrm{j}$ & 78.8 & $\mathrm{~g}$ & 3.5 & $\bar{i}$ \\
\hline & $80 *$ Control & 31.1 & $\mathrm{~h}$ & 75.3 & $\mathrm{~g}$ & 3.9 & $\mathrm{~h}$ \\
\hline & $100 *$ Control & 29.4 & $\mathrm{i}$ & 69.9 & $\mathrm{~h}$ & 3.7 & $\mathrm{i}$ \\
\hline & $60 *$ Biogent & 34.5 & $\mathrm{~g}$ & 98.5 & $\mathrm{f}$ & 5.0 & $\mathrm{~g}$ \\
\hline & $80 *$ Biogen & 37.6 & $\mathrm{e}$ & 107.6 & $\mathrm{e}$ & 5.6 & $\mathrm{e}$ \\
\hline & $100 *$ Biogen & 35.7 & $\mathrm{fg}$ & 99.8 & $\mathrm{f}$ & 5.2 & fg \\
\hline & $60 *$ Mycrrohizaen & 43.1 & $\mathrm{bc}$ & 123.1 & $\mathrm{c}$ & 6.3 & $\mathrm{~cd}$ \\
\hline & 80*Mycrrohizaen & 47.0 & $\mathrm{a}$ & 134.5 & $\mathrm{a}$ & 7.0 & $\mathrm{a}$ \\
\hline & $100 *$ Mycrrohizaen & 44.7 & $\mathrm{~b}$ & 124.7 & $\mathrm{c}$ & 6.5 & $\mathrm{~b}$ \\
\hline & $60 * \operatorname{Mix}$ & 41.6 & $\mathrm{~d}$ & 119.9 & d & 6.1 & $\mathrm{~d}$ \\
\hline & $80 *$ Mix & 44.7 & $\mathrm{~b}$ & 128.0 & $\mathrm{~b}$ & 6.5 & $\mathrm{~b}$ \\
\hline & $100 *$ Mix & 43.9 & $\mathrm{c}$ & 126.4 & $\mathrm{~b}$ & 6.3 & $\mathrm{c}$ \\
\hline
\end{tabular}

It is obvious from the data that Microhiza appear a high content of the studied chemical constituents in plant than Biogen and the mix of them, respectively. The results appeared also that irrigation level at $80 \%$ gave the highest content of chlorophyll, starch and total carbohydrates of the 
potato yield. Meanwhile the maximum values of the content of chlorophyll, starch and total carbohydrates of the tuber potato yield recorded with application of Microhiza at $80 \%$ irrigation level. While the lowest values obtained at $60 \%$ irrigation level without any inoculation. This result agree with Ghorbany et al. (2019) who emphasized that the highest means of chlorophyll content were obtained from interactions of normal irrigation $\times$ Mycorrhiza.

\section{Conclusion}

There are many challenges face the agriculture sustainability. Thus it is imperative to implementation and development of intensified sustainable agriculture practices tending toward sustainable agriculture systems. Natural biofertilizers influences important ecosystem services such as plant productivity, nutrient retention, soil microbial community, numerous soil properties and enhance ecosystem sustainability. For this reason, the objective of this work was to detect the role of the bioinoculation of Mycrrohizae or Biogen biofertilizers or the Mix of them in confronting one of the most vital challenge facing the world in the course of climate change (shortage of irrigation water) and how it can surmount its effect on ecosystem sustainability. In our study, Mycorrhizae or Biogen biofertilizers or the Mix of them appeared remarkable role in sustainable growth and development of Potato plants to acclimatize the water-limited conditions ( $60 \%$ irrigation level) for their better survival, this can observe on studied growth characteristic. Application of tested biofertilizers improved plant height, number of leaves, plant fresh weight and dry weight, Leaf area, total tuber yield in number per plant, total tuber yield in weight per plant, firmness and tuber volume of ten tubers that was turn on the yield quantity and quality for the marketable potato crop while it has appositive effect on chemical constituents as total chlorophyll, total carbohydrates and starch. Also it can enhance ecosystem sustainability by influencing soil properties including soil aggregate and nutrient availability (N, P and $\mathrm{K}$ ) and soil microorganisms obtained counts of total and spore forming bacteria and mycorrhizal spores count $/ 250 \mathrm{~g}$ soil, while this beneficial emerging properties could be efficiently exploited in the sustainable agriculture. Results indicated that Mycrrohizae was more effective than other treatments on all studied characteristics especially at proper irrigation level. While, combination of Mycrrohizae with irrigation level $80 \%$ registered the maximum values of studied parameters that in turn improved quantitative and qualitative of the potato production.

\section{Reference}

AbdelKader, H.H., H.Y.A. Massoud, A.A. Mosa, E.A. Eisa and E.A.E. Nour Eldeen, 2014. Effect of bio-fertilizers and plant extracts on growth, essential oil and chemical constituents of sage (Salvia officinalis L.) plant, under water stress conditions. Plant Production. 5 (6): 1003-1020.

A.O.A.C., 1975. Association of Official Methods of Analytical Chemists, Official Methods of Analysis 15 th ed. Washington, D.C., U.S.A.

A.O.A.C., 2005. Official Methods of Analysis: Association of Official Analytical Chemists. $16^{\text {th }}$ Eddition, Washington. DC. 577-581.

Alalaf, A.H. and N.N.F. Hadeed, 2020. Response of local orange grafted to the date of grafting chemical, organic and biological fertilization. Middle East journal of Agriculture Research . 9 (2): 444-454.

Anita, I. and B. Andrea, j2020. The Myth of Climate Smart Agriculture. $3^{\text {rd }}$ edition. https://www.arc2020.eu/the-myth-of-climate-smart-agriculture-why-less-bad-isnt-good/.

Bhattarai S. P., N. Su and D.J. Midmore, 2010. Sustainable irrigation to balance supply of soil water, oxygen, nutrients and agro-chemicals. Book chapter of biodiversity, biofuels, agroforestry and conservation agriculture, 253-286.

Bierman, B. and R.G. Linderman,1983. Use of vesicular-arbuscular mycorrhizal roots, intraradical vesicles and extraradical vesicles as inoculum. New Phytol., 95: 97-105.

Bouamri, R., Y. Dalpé, M.N. Serrhini and A. Bennani,2006. Arbuscular mycorrhizal fungi species associated with rhizosphere of Phoenix dactylifera L. Morocco. Afr. J. Biotechnol., 5, 6: 510516 ,

Brundrett, M., N. Bougher, B. Dell, T. Grove and N. Malajczuk, 1996. Working with mycorrhizae in forestry and agriculture. ACIAR Monograph 32, $374 \mathrm{pp}$. Australian centre for international agricultural research, canberra. 
Chapman, H.D. and P.F. Pratt, 1961. Methods of Analysis for Soil, Plant, and Water. Division of Agr. Sc. University of California.

Clark F.E., 1965. Agar plate methods for total microbial count in methods of soil analysis, Part 2. Agronomy, Am. Soc. Agronomy Inc., Madison, Wis., USA., 1460-1466.

Cosentino, S.L., P. Cristina, S. Emanuele, C. Venera and F. Salvatore, 2007. Effects of soil water content and nitrogen supply on the productivity of Miscanthus $\times$ giganteus Greef et Deu. In a Mediterranean environment, Industrial Crops and Products, 25 (1): 75-88.

Crespo, R., 2015. Impact of arbuscular mycorrhizal fungi on the physiology of maize under variable nitrogen and phosphorus levels. Theses, Dissertations, and Student Research in Agronomy and Horticulture. 87. http://digitalcommons.unl.edu/agronhortdiss/87.

Deja-Sikora, E., A. Kowalczyk, A. Trejgell, A. Szmidt-Jaworska, C. Baum, L. Mercy and K. Hrynkiewicz, 2020. Arbuscular mycorrhiza changes the impact of potato virus Y on growth and stress tolerance of Solanum tuberosum L. in vitro. Front. Microbiol. 10:2971. doi: 10.3389/fmicb.2019.02971.

El-Salhy, A.M., H.A. Abd El-Galil, A.H. Abd El-Aal and M.M. Ali, 2010. Effect of different Nitrogen fertilizer sources on vegetative growth, nutrient status and fruiting of Balady Mandarin trees. Scientists Fac. of Agric. Assiut Univ. 27 (153-170).

El-Sayed, S.F., A.H. Hassan and M.M. El-Mogy, 2015. Impact of bio- and organic fertilizers on potato yield, quality and tuber weight loss after harvest. Potato Res., 58:67-81.

Fawzy, Z.F., A.M. El-Bassiony, L. Yunsheng, O. Zhu and A.A. Ghoname, 2012. Effect of mineral, organic and bio-N fertilizers on growth, yield and fruit quality of sweet pepper. Journal of applied sciences research. 8 (8): 3921-3933.

FAO, 1980. Soil and Plant Analysis. Soils Bulletin, 38: 2-250.

Frey-Klett, P., M. Chavatte, M. Clausse, S. Courrier, C. Le Roux, J. Raaijmakers, G.M. Maria, J. Pierrat and J. Garbaye, 2015. Ectomycorrhizal symbiosis affects functional diversity of rhizosphere fluorescent pseudomonads. New Phytologist. 165: 317-328.

Garcia S. and J. Racsko, 2018. The role of arbuscular mycorrhizal fungi in plant nutrition. plant health.

Gendy, A.S.H., H.A.H. Said-Al Ahl, A.M. Abeer and F.Y. Hanaa, 2013. Effect of nitrogen sources, bio-Fertilizers and their interaction on the growth, seed yield and chemical composition of guar plants. Life science journal. 10 (3). http://www.lifesciencesite.com.

Ghorbany, M., S.H.R. Ramazani, H. Fallahi and S.M.M. Koohi, 2019. Effect of drought stress and biofertilizer on yield and yield components of guar (cyamopsis tetragonoloba L.) taub. Journal of medicinal plants and by-products. 1: 13-19.

Giovannini, L., M. Palla, M. Agnolucci, L. Avio, C. Sbrana, A. Turrini and M. Giovannetti, 2020. Arbuscular mycorrhizal fungi and associated microbiota as plant biostimulants: research strategies for the selection of the best performing inocula. Agronomy. 10 (1), 106; 106. https://doi.org/10.3390/agronomy10010106.

Gomez, K.A. and A.A., Gomez, 1984. Statistical Procedures for Agricultural Research. 2nd Edition, John Wiley and Sons Inc., New York.

Herman, D.J., M.K. Firestone, E. Nuccio, and Hodge, 2012. Interactions between an arbuscular mycorrhizal fungus and a soil microbial community mediating litter decomposition. FEMS Microbiol. Ecol., 80: 236-247.

Hodge, A., 2014. Interactions between arbuscular mycorrhizal fungi and organic material substrates, chapter two In: Advances in applied microbiology, editor(s): sima sariaslani, geoffrey michael gadd, academic press, 89, PP: 47-99.

Hosseny, M.H. and M.M.M. Ahmed, 2009. Effect of nitrogen, organic and biofertilizer on productivity of lettuce (CV. Romaine) in sandy soil under assiut conditions. Ass. Univ. Bull. Environ. Res. 12 (1).

Jacobs, M.B. and M.J. Gerstein, 1960. Hand-book of microbiology. D. Van (Ed) Nostrand Co., Inc., New York: 139-202.

Janet, D., 2020. The Effects of Mycorrhizal Fungi Inoculum on Potato Yield. UCCE Master Gardener Program of San Mateo \& San Francisco Counties. http://smsfmastergardeners.ucanr.edu/Elkus/Michrorizall_test_on_Potatoes/ 
Kandowangko, N.Y., G. Suryatmana, N. Nurlaeny and R. Simanungkalit, 2009. Proline and abscisic acid content in droughted corn plant inoculated with azospirillum sp. and arbuscular mycorrhizae fungi. Journal of biosciences. 16 (1): 15-20 .

Khalid, M., D. Hassani, M. Bilal, F. Asad, and D. Huang, 2017. Influence of bio-fertilizer containing beneficial fungi and rhizospheric bacteria on health promoting compounds and antioxidant activity of Spinacia oleracea L. Bot. Stud. 58 (1): 35.

Koske, R.E. and J.N. Gemma, 1989. A modified procedure for staining roots to detect VA mycorrhizas. Mycol. Res. 92:486-488.

Levene, H., 1960. Robust tests for equality of variances. Essays in Honor of Harold Hotelling. In: Olkin I, Ghurye SG, Hoeffding W, Madow WG, Mann HB (eds) Contributions to probability and statistics. Stanford University Press, Palo Alto, p 292.

Lone, R., R. Shuab, V. Sharma, V. Kumar, R. Mir and K. Koul, 2015. Effect of arbuscular mycorrhizal fungi on growth and development of potato (Solanum tuberosum) Plant. Asian journal of crop science 7 (3): 233-243.

Ma, M., M. Ongena, Q. Wang, D. Guan, F. Cao, X. Jiang and L. Jun, 2018. Chronic fertilization of 37 years alters the phylogenetic structure of soil arbuscular mycorrhizal fungi in Chinese Mollisols. https://doi.org/10.1186/s13568-018-0587-2.

Manitoba, 2013. Effects of manure and fertilizer on soil fertility and soil quality. http://www.gov.mb.ca/agriculture/environment/nutrient.

Miransari, M., 2013. Soil microbes and the availability of soil nutrients. Acta Physiol Plant. 35:30753084.

Nuccio, E.E., A. Hodge, J. Pett-Ridge, D.J. Herman, P.K. Weber and M.K. Firestone, 2013. An arbuscular mycorrhizal fungus significantly modifies the soil bacterial community and nitrogen cycling during litter decomposition. Environ. Microbiol. 15: 1870-1881.

Sharma, K., S. Sharma and S.R. Prasad, 2019. PGPR: Renewable tool for sustainable agriculture. International journal of current microbiology and applied sciences. 8(1): 525-530.

Simpson, D. and M.J. Daft, 1990. Interactions between water stress and different mycorrhizal inocula on plant growth and mycorrhizal development in maize and sorghum. Plant Soil 121, 179-186. https://doi.org/10.1007/BF00012310.

Smith, S.E. and F.A. Smith, 2011. Roles of arbuscular mycorrhizas in plant nutrition and growth: new paradigms from cellular to ecosystem scales. Ann Rev Plant Biol 62:227-250

Smith, F.M.A., G.D.K. Hamilton and P.A. Geeds, 1956. Colorimetric method for determination of sugar and related substances. Anal. Chem., 28: 550.

Susiana, P., I. Rukmi and S.N. Jannah, 2019. Applications of mycorrhiza on potato growth and productivity. Journal of Physics (1217): 1742-6596.

Vale, M., B. Mary and E. Justes, 2007. Irrigation practices may affect denitrification more than nitrogen mineralization in warm climatic conditions. Biol. Fertil. Soils, 10.1007-1016.

Vegetable cultivation guide, Extension Publish No. 14-2014. Agriculture Research Center, Ministry of Agriculture and Land Reclamation, Egypt.

Volpato, S., G. Masoero, G. Giovannetti and M. Nuti, 2020. Arbuscular mycorrhizal biofertilizers sources in the potato (Solanum tuberosum) plant show interactions with cultivars on yield and litter-bags spectral features. Journal of agronomy and research. 2 (4): 2639-3166.

Watanabe, F.S. and S.R. Olsen, 1965. Test of an Ascorbic Acid Method for Determining Phosphorus in Water and $\mathrm{NaHCO}_{3}$ Extracts from the Soil. Soil Science Society of America Journal, 29, 677678.

Wills, R.B.H., T.H. Lee, D. Grahum, W.B. McGlasson, and E.G. Hall, 1982. Postharvest an introduction to physiology and handling of fruit and vegetables. Inc., Westport, Connecticut, P.64.

Xavier, L. and J. Germida, 2002. Response of lentil under controlled conditions to co-inoculation with arbuscular mycorrhizal fungi and rhizobia varying in efficacy. Soil Biol. Biochem. 34 (2), 181188.

Yooyongwecha, S., T. Samphumphuangb, R. Tisarumb, C. Theerawitayab and S. Cha-umb, 2016. Arbuscular mycorrhizal fungi (AMF) improved water deficit tolerance in two different sweet potato genotypes involves osmotic adjustments via soluble sugar and free proline. Scientia Horticulturae, 198: 107-117. 